\title{
Learning to Improve: Report of a Three-Year Capacity-Building Project Leveraging Professional Development + Coaching to Improve Third-Grade Reading Outcomes
}

\author{
David D. Paige1, Grant S. Smith¹, Theresa Magpuri-Lavell² \\ ${ }^{1}$ Bellarmine University, Louisville, KY, USA \\ ${ }^{2}$ Sandra Dunagan Deal Center for Early Language and Literacy, Georgia College, Milledgeville, GA, USA \\ Email: dpaige@bellarmine.edu, gsmith2@bellarmine.edu, theresa.magpurilavell@gcsu.edu
}

How to cite this paper: Paige, D. D., Smith, G. S., \& Magpuri-Lavell, T. (2019). Learning to Improve: Report of a ThreeYear Capacity-Building Project Leveraging Professional Development + Coaching to Improve Third-Grade Reading Outcomes. Advances in Literary Study, 7, 193-223. https://doi.org/10.4236/als.2019.74013

Received: May 27, 2019

Accepted: October 11, 2019

Published: October 14, 2019

Copyright $\odot 2019$ by author(s) and Scientific Research Publishing Inc. This work is licensed under the Creative Commons Attribution International License (CC BY 4.0).

http://creativecommons.org/licenses/by/4.0/

\begin{abstract}
This study reports the results of a three-year capacity building effort to improve core reading knowledge and practice in 165 third-grade teachers working in 63 urban schools and its effects on student reading outcomes. Teachers volunteered to participate in one or two years of professional development lasting from 90 to 180 hours. Core reading knowledge among teachers resulted in statically significant growth with generally large effect sizes. Three cohorts of third-grade students taught by participating teachers were assessed on multiple measures of reading at the beginning and end of each school year. Results for within-year improvement showed large effects on all student outcomes. Analysis of the magnitude of student gains between the three years found that for two of the four measures gains in year one were exceeded in years two and three. Implications for professional training to facilitate improved reading outcomes are discussed.
\end{abstract}

\section{Keywords}

Teacher Capacity Building, Foundational Reading Skills, At-Scale Reading Improvement

\section{Introduction}

Calls for reading improvement have echoed for decades and include those from Flesch (1955), Anderson, Hiebert, Wilkinson, \& Scott (1985), Snow, Burns, \& Griffin (1998), the National Reading Panel (2000), Foorman et al. (2016), and Seidenberg (2017). Accompanying these calls are reading achievement scores 
from the National Assessment of Educational Progress (NAEP, 2017) that have shown little substantive improvement since 1992. Today, close to two-thirds of students score less than-proficient in reading at the fourth- and eighth-grade levels. Despite the considerable body of research that has advanced the science of reading (Rayner, Pollatsek, Ashby, \& Clifton, 2012) evidence suggests that philosophical differences of reading remain tightly ensconced among teacher educators who directly impact the reading praxis taught in teacher preparation programs (Kato \& Manning, 2007; Huang, 2014; Taylor \& Otinsky, 2007). As Seidenberg (2017) suggests, these disparate philosophies among teacher educators make their way into the classroom and lead to frustration, low job satisfaction, and children who cannot read. Seidenberg observes that teachers are:

Left to discover effective classroom practices [on their own] because they haven't been taught them. One of their first discoveries is the irrelevance of most of the theory they have learned that is unconnected to practice. Some of the concepts are impractical, or don't work, or don't work as well as something else, like instruction. (p. 255)

The Common Core standards (2010) identify foundational skills as the reading sub-skills involved in converting print to speech and the fluent reading skills that are important to comprehension. Extending the link from language to comprehension, a recent study has found that foundational skills are critical to third-grade achievement on end-of-year state accountability assessments (Paige et al., 2019). The authors reported that students with appropriate foundational skills were seven times more likely to score proficient or better on the state reading test. Further, only one-third of the over 1000 students in the study had attained appropriate foundational skills. Using professional development and coaching to build capacity for teaching reading, the present study reports on an initiative to improve third-grade reading outcomes. This study contributes to the knowledge base of educational change through a description of the teacher training process and the measurement of the student outcome measures that detect improvement in fundamental reading processes.

The structure of this article proceeds with a review of the applicable literature including the role of teacher core and pedagogical knowledge, attempts to change and build teacher practice, and the role of coaching. The study continues with a description of the methods including details of the study context and the curriculum used to improve teacher knowledge and practice, as well as the instruments used to measure reading. In the results section, we address each of the three research questions with details of the quantitative analysis and the findings. In the discussion section, we provide our interpretations of the study findings and the contribution this study makes to the literature base.

\section{Review of the Literature}

\subsection{Teacher Knowledge and Practice}

The foundational reading knowledge imparted by teacher educators to their 
students leaves a significant imprint on how these aspiring teachers view reading education. Teacher educators also equip these students with an initial instructional toolkit that is carried with them into the classroom after graduation. However, for too many of these future teachers this toolkit is woefully inadequate. Binks-Cantrell, Washburn, Joshie, \& Hougen (2012) assessed what teacher educators understand about foundational reading knowledge. After grouping teacher educators into higher- and lower-scoring groups the authors reported that those in the more knowledgeable group produced teacher candidates who outscored those taught by teacher educators who knew less. The authors concluded that students cannot learn what their teacher does not know and join others who have proposed this condition as a major contributor to poor reading outcome in the United States (Applegate \& Applegate, 2004; Seidenberg, 2017). Unfortunately, changing what is taught by teacher educators in the over 1200 schools of education in the US is more than a challenging task. For example, in a state-wide analysis of teacher data in Florida, Harris \& Sass (2007) found no evidence that either undergraduate training or academic achievement had any effect on the academic outcomes of their future students.

\subsection{Changing Teacher Practice}

What teachers do in the classroom matters because reading is a learned skill that must be taught, and so it follows that teacher quality impacts student outcomes (Blair, Rupley, \& Nichols, 2007; Wenglinsky, 2000; Wharton-McDonald, Pressley, \& Hampston, 1998). In order to be effective reading instruction must be guided by content knowledge and efficacious instructional practices (Kennedy, 2016; Sparks \& Loucks-Horsley, 1990). As in subject areas such as biology or history, there exists a core body of content knowledge that teachers must know in order to be effective reading teachers (Snow \& Griffin, 2007). Reading core content includes deep knowledge of phonemic awareness, phonics, fluency, vocabulary and comprehension, as well as the fundamentals of language and its development (McCardle \& Chhabra, 2004; NRP, 2000; Snow, Burns, \& Griffin, 1998). In order to provide evidence-based reading instruction teachers must not only possess core content knowledge, they must also have the ability to effectively apply that knowledge to classroom practice (Goldhaber \& Anthony, 2007; McCardle \& Chhabra, 2004; Moats, 2004; NRP, 2000).

An initiative to improve teacher core reading knowledge must be intentional. After identifying what knowledge and which instructional practices best result in improved reading outcomes, the question becomes how to effectively 1) transfer this knowledge to teachers and then 2) convert that knowledge into instructional change that results in improvement (Shulman, 1986, 1987). Knowledge-to-practice transfer is not an inconsequential problem as greater teacher knowledge is not necessarily accompanied by better practice (Reutzel, Dole, Fawson, Jones, Read et al., 2009). A compounding problem is that teachers report that $90 \%$ of professional development is not useful as some suggest it too often consists of ineffec- 
tive delivery models (Darling-Hammond et al., 2009). It has been estimated that about 15 percent of traditional "sit and get" professional development is actually implemented in the classroom, a transfer ratio that provides less than the necessary capacity to affect change (Meyer, 1988). Bush (1984) found that training describing instructional practices could be successfully adopted by just $10 \%$ of teachers, in other words $90 \%$ gained no benefit at all. This suggests that an effective model must provide considerably more support over time as teachers struggle to implement new instructional practices (Ermeling, 2009; Fullan, 2001). However, an ineffective delivery model may not be the single root cause of the poor return on PD. It may be, as Elmore (2000) points out, that PD may not target the content most likely to result in change to student outcomes. This may be a problem that both precedes and interacts with complaints of ineffective delivery models as improvement experts are clear that capacity training must address the processes that will actually result in change (Bryk, 2014; Elmore, 2002; Demming, 2000).

\subsection{Building Teacher Capacity}

PD directly addresses the issue of capacity which Cohen, Raudenbush, \& Ball (2000) define as the teacher's knowledge, instructional skill, and material resources that combine to create the interaction among students, the content, and the teacher to result in learning. Desimone (2009) posits that effective professional development (PD) increases teacher knowledge and skill, which then leads to change in instruction that results in greater student learning. While this seems a reasonable theory of action it has seldom been shown to actually evolve. A review of 1343 PD studies (Yoon et al., 2007) found just nine meeting the requirements of What Works Clearinghouse that resulted in significant student gains. This suggests that connecting the links recommended by Desimone is extremely difficult. Looking further into recommendations, Lewis (2009) says that PD must connect what teachers learn directly to their practice. For example, Garet et al. (2001) report that effective PD must focus not only on content knowledge, but also include opportunities for active learning integrated with instruction. Despite these recommendations, researchers have found teacher practice to be surprisingly resilient to change (Cohen, 1990; Peterson \& Comeaux, 1990; Spillane \& Zeuli, 1999). Unfortunately, inadequate teacher knowledge is not limited to reading as insufficiencies have been noted across other content areas including teachers of science (Dorph et al., 2007; Luft \& Hewson, 2014) and mathematics (National Council of Teachers of Mathematics, 1991).

Gulamhussein (2013) recommends five criteria for effective professional development, three of which overlap with those of Desimone (2009) and two that do not. Duration of professional development is critical and should emphasize distributed practice over time. While programs providing greater duration have been found to be more successful, a question is how much is enough (Darling-Hammond, Wei, Andre, Richardson, \& Orphanos, 2009). Corcoran, 
McVay, \& Riordan (2003) found that programs providing 80 hours of instruction were more likely to be successful than those providing less. French (1997), on the other hand, found that 50 hours of instruction, practice, and coaching was sufficient to transfer learning to instruction. Teachers must be supported during the critical process of applying new learning to the classroom. Truesdale (2003), Cornett \& Knight (2009), and Atteberry \& Bryk (2011) report that during the confusion and frustration that accompanies the implementation of new teaching strategies and routines, coaching can provide teachers with critical support. Active learning involves teachers in a variety of learning approaches to new concepts (Richardson, 1998; Roy \& Chi, 2005). Such activities include implementation videos, role playing, reading, discussion, and modeling. Of these activities modeling has been viewed as most effective (Desimone, et al., 2002; Garet et al., 2001; Penuel, Fishman, Gallagher, Korbak, \& Lopez-Prado, 2009). The final principle states that professional development should focus on content specific curriculum as it is most effective at improving teacher practice and student achievement (Blank \& de las Alas, 2009; Cohen \& Hill, 2001; Kennedy, 1998).

In their What Works Clearinghouse review, Yoon et al. (2007) arrived at the following conclusions of what drives effective PD. First, while workshops have garnered a poor reputation for effectiveness, surprisingly, all 9 of the studies found to be effective involved workshops of some kind. Second, within-school expertise is often insufficient to facilitate and lead teachers in capacity-building initiatives aimed at student improvement. Successful professional development is more likely to be successful when involving content experts from outside the building. Third, none of the 9 successful studies employed a train-the-trainer approach to professional development which may hold potential for success, but has no evidence for support. Fourth, professional development must be distributed over time as educators cannot quickly absorb new learning. Effective PD was found to take 30 or more hours while implementations of shorter duration yielded no positive results. The fifth finding suggests that following professional development sustained follow-up is necessary to leverage its potential for effectiveness. Finally, there is no set of best practices for PD, rather, effective PD is constructed from a carefully considered mix of practices customized by content, process, and the context of the particular school building.

\subsection{Coaching}

An element now recognized across education as critical to successful adoption of new skills is teacher coaching. While there has been a considerable amount written on what authors consider to be the important characteristics and responsibilities of coaches, reports on the effectiveness of coaching have been slower to emerge (Bean, Swan, \& Knaub, 2003; Dole, 2004; Vanderburg \& Stephens, 2010). However, unlike PD, empirical findings are increasingly supporting the notion that coaching has a measurable, positive effect on teacher performance (Gamse, Jacob, Horst, Boulay, \& Unlu, 2008; Garet et al., 2008). In a 
state-wide middle school study Marsh et al. (2008) found a small, positive effect of coaching on the reading achievement in two of four student cohorts. Newman \& Cunningham (2009) as well as Sailors \& Price (2010) both found workshop training plus coaching out-performed teachers receiving workshop training only on measures of classroom practice. Matsumura, Gernier, Correnti, Junker, and Bickel (2010) determined that coaching accounted for increases in effective teacher practice that could be attributed to student achievement increases with an effect size equal to 0.51 . A four-year study of coaching effects on kindergarten through second-grade learning across 17 schools was conducted by Biancarosa, Bryk, \& Dexter (2010). Beginning with a baseline of student reading outcomes, the authors compared growth over four years and found that coaching could be attributable to increases in reading achievement with statistically significant effect sizes of $0.22,0.37$, and 0.43 across the three years following the baseline year. Finally, Davis, McPartland, Pryseski, and Kim (2018) found that the use of literacy coaches to assist ninth-grade teachers in the use and implementation of literacy strategies resulted in improved student reading comprehension with an effect size of 0.19 .

\subsection{Research Questions}

The present study is part of a three-year professional development initiative to improve end-of-third-grade reading outcomes by improving teacher capacity for reading instruction from kindergarten-through third-grade. This study investigates changes in third-grade teacher reading knowledge as a result of PD and the resulting student reading outcomes through a focus on three research questions:

RQ1: To what extent does teacher core reading knowledge change as a result of capacity training delivered within the project?

RQ2: How do third-grade student reading outcomes in the areas of spelling knowledge, pseudo- and sight-word reading, and reading fluency change over the three years of the project?

RQ3: What is the magnitude of student learning across years?

\section{Method}

\subsection{District}

Jefferson County Public Schools (JCPS) is located in Louisville, Kentucky and serves approximately 100,000 students, making it the $27^{\text {th }}$ largest public-school district in the United States. Of the students attending the district $37 \%$ are of African-American ethnicity, 49\% are European-American, 7\% are Hispanic, while the remainder are of other backgrounds. Sixty-two percent of students attending the district receive free- or reduced-price lunch. On the most recent National Assessment of Educational Progress (NAEP, 2017), 64\% of fourth-grade students across JCPS scored at the basic level or below. Achievement on the NAEP by African-American students in the fourth-grade is 32 points (15.8\%) lower than for children of European-American descent. A look at the Kentucky 
Department of Education (2017) state reading achievement test scores (KPREP) reveals that well over half (53.6\%) of JCPS students achieve at less-than-proficient levels. When these scores are broken out by ethnicity nearly $60 \%$ of European-American children achieve proficiency compared to $28.9 \%$ of African-American children. This disparity is important as the present study is conducted in schools largely attended by African-American children and others from disadvantaged backgrounds.

\subsection{Project Background}

The Jefferson County Public Schools Literacy Project (Project) was a university-district initiative between JCPS and literacy educators from Bellarmine University with a goal of increasing end-of-third-grade reading outcomes. The theory of action adopted by the Project was that of Desimone (2009) where improving teachers' core reading knowledge and pedagogical skill with the help of literacy coaches, improves core (tier 1) instruction and results in improved student reading outcomes. The Project adopted the fundamental idea that to substantially improve reading outcomes teachers must be deeply knowledgeable about how printed words are transferred into sound and meaning by the reader. Teachers must also be highly skilled in the pedagogy that facilitates letter-sound correspondence and the transfer of that knowledge into appropriate reading fluency with comprehension. As such, the Project took the approach that everyone involved in reading instruction must learn to improve, and that this learning is not to a criterion, but rather, grows on a continuous improvement continuum.

The district had in place a "Third-Grade Reading Pledge," an aspirational goal that all end-of-third-grade students would be reading on grade-level, although grade-level was left undefined. In the fall of 2013, the district's Chief Academic Officer invited area schools of education to propose initiatives to facilitate achievement of the third-grade reading pledge. The proposal from Bellarmine was based on the design of prior reading academies initiated in Dallas and Memphis (Manzo, 2000; Feldman, Schneck, Feighan, Coffey, \& Rui, 2011). The Project was reviewed by the District and ultimately approved by the JCPS Board of Education. Project funding came primarily from Title 1 and general funds to pay delivery costs to Bellarmine. Deliverables included the design and delivery of a one-year capacity-building curriculum for kindergarten through third-grade teachers, ESL and Special Education teachers, the training of literacy coaches, designing a student outcome assessment system, collecting and analyzing data, and generally overseeing the Project in conjunction with district administrators. The first-year success of the Project resulted in the annual renewal of the project over the next two years. Total expenditures by the district for the three years amounted to approximately $\$ 2.5$ million.

\subsection{School and Teacher Participation}

In the spring of 2014, the now Board-approved Project was presented to prin- 
cipals of the 19 lowest performing elementary schools as a major initiative to assist them in increasing the teaching capacity necessary to improve attainment of the third-grade reading pledge. As part of Kentucky's educational reform act (Kentucky General Assembly, 1990) the state incorporated site-based decision making (SBDM) teams at every public school in the state. SBDMs became public policy with the primary intention of giving parents and school-based personnel a voice in the management of their school. As such, each SBDM team is composed of six members that include the principal, two parents, and three faculty members. Among other duties the SBDM must approve to participate in district-proposed projects. Principals at each of the 19 schools presented the Project to their SBDM for consideration with all schools voting to participate. Once approved, principals began to solicit the voluntary participation of their teachers in the year-long training initiative and identified a school-based literacy coach. Teachers received no monetary compensation for participation in the Project. However, teachers did receive a total of six hours (3 hours per semester) of graduate level credit at no cost to them and were provided the books required for class. Graduate credit was granted by Bellarmine University and could be applied toward a degree at Bellarmine or transferred to another institution. Classes were delivered weekly in elementary schools that were in proximity to participating schools to ease travel for teacher participants. One year of classes resulted in 90 hours of face-to-face training over the two courses.

By the end of Year 1 many teachers were requesting a second year of training to better extend what they had learned. This resulted in the design of a third and fourth course available to teachers who had completed the initial foundational year of training. For participation in the second year of advanced training, teachers received an additional six hours of graduate credit, again at no cost to them, bringing the total of earned graduate credit to 12 hours for those completing two years of training. This second year of face-to-face training provided an additional 90 hours of training. Teachers participating in both years of training received a total of 180 hours of professional development.

Project training was open to teachers from K-3, special education, and ESL classrooms. Across the three project years a total of 162, 224, and 200 teachers enrolled in training in years 1, 2, and 3 respectively for a total enrollment of 586 teachers. Table 1 shows that in the first year of the project 46 third-grade teachers completed foundational training. In project Year 2, 61 third-grade teachers completed foundational training while $23(50 \%)$ teachers from Year 1 completed advanced training, bringing Year 2 enrollment total to 84 . Year 3 saw 58 thirdgrade teachers complete foundational training while 30 (49\%) teachers completed advanced training. In total, 88 teachers completed training in Year 3.

At the conclusion of Year 1 district leaders were anxious to make the Project available to additional schools. With a total of 90 elementary schools across the district, the primary criterion used by the district to identify additional schools was success on end-of-year state achievement tests. Schools performing poorly 
on this test were viewed as being in need of capacity training to assist their teachers in efforts to better achieve the third-grade reading pledge. Beyond the initial 19 schools, the next group identified as most in need of assistance resulted in twenty-six schools joining the Project in Year 2 for a total of 45 schools. The following year 18 additional schools were identified by the district, bringing to 63 the number of participating schools in Year 3. Schools identified by the district went through the same SBDM procedures as the initial 19 schools.

\subsection{Course Content}

The theory of action (Figure 1) adopted by the Project is one hypothesized by Desimone (2009) where professional development and literacy coaching improves teacher knowledge and skill, which then leads to improved classroom teaching and ultimately, to improved student reading outcomes. This put the primary focus of the Project on the improvement of Tier 1 or core instruction. Training was conducted through traditional face-to-face classes that met 15 times from August through December, and another 15 sessions that met from January to May with instructors hired from the district and trained and monitored by the Project leader. Each session lasted 3 hours resulting in a total of 90 training hours across the school year. Training was conducted during Year 1 (2014-15), Year 2 (2015-16), and Year 3 (2016-17) with Year 2 and 3 training

Table 1. Third-grade teacher participation by cohort year.

\begin{tabular}{|c|c|c|c|c|}
\hline & & \multicolumn{3}{|c|}{ Year } \\
\hline & & $\stackrel{1}{(2014-15)}^{-}$ & $\left.\stackrel{2}{\frac{2}{5}}-16\right)$ & $\frac{3}{3}$ \\
\hline \multicolumn{2}{|c|}{ Schools } & 19 & 26 & 18 \\
\hline \multicolumn{2}{|c|}{ Schools (cumulative): } & 19 & 45 & 63 \\
\hline \multicolumn{5}{|c|}{ Teachers: } \\
\hline \multicolumn{2}{|c|}{ Foundational Training (90 hours): } & 46 & 61 & 58 \\
\hline \multicolumn{2}{|c|}{ Advanced Training (90 additional hours): } & 0 & 23 & 30 \\
\hline \multicolumn{2}{|c|}{ Teacher Total: } & 46 & 84 & 88 \\
\hline \multicolumn{2}{|c|}{ Unduplicated Cumulative Teacher Total: } & 46 & 107 & 165 \\
\hline \multicolumn{2}{|c|}{ Teacher Training Hours: } & 4140 & 7,560 & 7,920 \\
\hline \multicolumn{2}{|c|}{ Cumulative Teacher Training Hours: } & 4140 & 11,700 & 19,620 \\
\hline \multirow[t]{2}{*}{$\begin{array}{c}\text { Professional } \\
\text { Development }\end{array}$} & $\begin{array}{c}\text { Teacher Knowledge } \\
\text { and Skills }\end{array}$ & \multicolumn{2}{|c|}{$\begin{array}{l}\text { Classroom } \\
\text { Teaching }\end{array}$} & $\begin{array}{c}\text { Student } \\
\text { Achievement }\end{array}$ \\
\hline & Literacy Coaching & & & \\
\hline
\end{tabular}

Figure 1. Project theory of action. 
consisting of both foundational and advanced training. Course content included the theoretical language processes involved in converting print to speech and the Big 5 reading processes (National Institute of Child Health and Human Development, 2000) of phonemic and phonological awareness, fluency, vocabulary and comprehension within the context of the Project's instructional delivery model. Teachers were taught how these processes work on an interactive basis to produce efficient reading with understanding. Teachers were trained and coached to implement reading instruction using the Project's instructional delivery model that provided a flexible framework for planning instruction based on student needs. A teaching and learning cycle for each of the Big 5 reading processes was utilized in coursework to ensure a comprehensive understanding of the subject matter and implementation with fidelity of the Project's instructional delivery model. The teaching and learning cycle included building background knowledge on each of the Big 5 reading processes, assessment for diagnosis, strategic instruction, and how to involve families and caregivers in the reading development of their child (Figure 2). As part of their training, teachers implemented classroom action plans (CAPs), assignments intended to assist in bridging coursework to classroom application. Embedded within the Project curriculum for the foundational training year were five CAPs that targeted specific teaching strategies associated with the Big 5 reading processes, one each for phonemic awareness, phonics, fluency, vocabulary, and comprehension. The advanced year of training included CAPs focused on systematic and differentiated word study and the implementation of guided reading to reinforce the connection to the instructional delivery model for reading instruction. Submission of weekly CAPs detailing the teaching and learning of the Big 5 reading

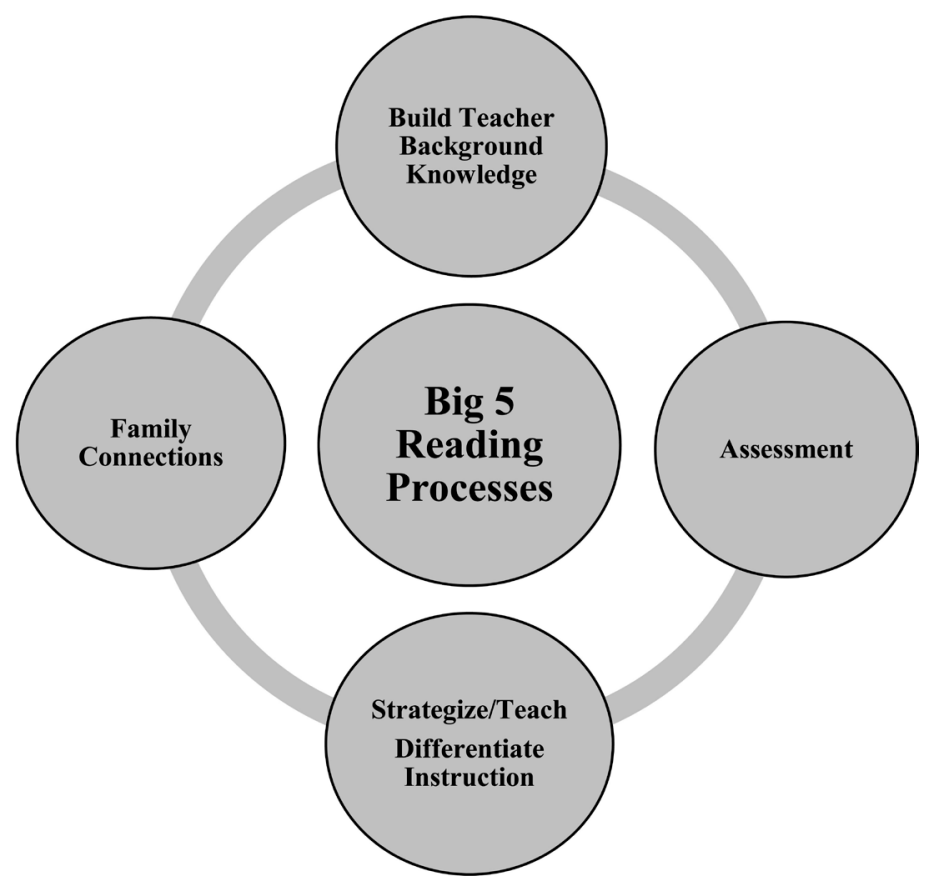

Figure 2. Teaching and learning cycle. 
processes and grade level Common Core Standards for English Language Arts within the Project's instructional delivery model was required in the advanced year of training. Also included in this year of training was a strong emphasis on assessment of the critical reading subskills related to efficient reading. These included diagnostic assessments that provided insight into the student's understanding of phonics, pseudo- and sight-word reading, and reading fluency (van Kuijk, Deunk, Bosker, \& Ritzema, 2016). This provided for data-driven instruction based on individual student need. Teachers also received additional training in teaching letter-feature analysis skills as well as oral reading fluency and comprehension instruction. Also emphasized was development of a multi-tier support structure (MTSS) for students who were struggling. Throughout the Project a formative approach to curriculum was maintained that allowed the training curriculum to be adjusted in response to the learning of teacher-participants (Jimenez, 1997; Reinking \& Bradley, 2004).

\subsection{Literacy Coaches}

In conjunction with the district, coaches were selected and then trained in the Project curriculum during a 2-week, 80 -hour long summer workshop. During the school year coaches met monthly as a group with Project leaders to share insights, discuss logistics of the Project, how best to assist teachers, refine coaching skills, and continually enhance subject matter knowledge. Coaches were also trained to develop trust and establish rapport with each teacher in order to provide useful suggestions based on best-practice for improved student outcomes. For each CAP, coaches engaged the participating teacher in a coaching cycle to provide support in the implementation of a new teaching strategy and to ensure continued use of the teaching strategy based on student need. As part of the coaching cycle the coaches held a pre-conference, observed an implementation of the strategy, and then held a post-conference with their respective Project teachers. Each pre- and post-conference session lasted up to 30 minutes. Additionally, and on an as-needed basis, coaches modeled strategies in participating classrooms.

Instructional coaching for elementary schools was administered by individuals with the title of Goal Clarity Coach. The scope of responsibilities for a Goal Clarity Coach was to provide support, assistance, and advice to the district-wide service center and/or the school faculty in the content area of need. Subject matter expertise of individual coaches tended to be wide-ranging from math to science to literacy across the elementary, middle, and high school level. During Year 1 of the Project, the responsibilities of literacy coaches were assigned by the district to the Goal Clarity Coach, when this was not possible it was given to a teacher leader. Initially Project literacy coaches were not compensated for these responsibilities. Over the course of the three years, Project literacy coaches were chosen with specific subject matter area expertise in elementary reading and eventually 50 percent of a coach's job responsibility was compensated by the 
district from general funds.

\subsection{Student Participants}

The unit of analysis for reading outcomes is conducted at the student level. The empirical student sample in the present study are third-grade students instructed by teachers participating in foundational and advanced training across the three years of the study. As the primary concern of district leaders was making the Project available on a wide basis, selection of a control-group was not possible. The number of third-grade teachers participating in the Project varied each year which resulted in a fluctuating number of students available for the analytic sample. After accounting for incomplete data and student mobility, the reported student samples for each Project year reflects an average of 13 to 20 students per Project teacher. While $62 \%$ of students attending district schools came from disadvantaged backgrounds, approximately $85.6 \%$ of students attending Year 1 and 2 schools are from backgrounds putting them at-risk for reading acquisition. While fewer students attending the Year 3 schools came from disadvantaged backgrounds, the overall percentage of $75 \%$ is well above the district average.

\subsection{Assessments}

\subsubsection{Literacy Instruction Knowledge Scale}

The Literacy Instruction Knowledge Scale (Reutzel et al., 2009 [LIKS]) is a standardized assessment that assesses a teacher's literacy content knowledge through a multiple-choice test composed of three subscales, two of which are used in this study. Teachers participating in foundational skill training were administered the LIKS in the beginning of the fall semester and again at the end of the spring semester. The decoding subscale has 32 items while the comprehension subscale contains 43 items. The total knowledge scale is the sum of the two scales reflecting a range of 0 to 75 . Internal consistency for each subscale reported by the authors of the LIKS are Cronbach's alpha of 0.68 for decoding and 0.77 for comprehension. Test-retest reliability for the two subscales reported by the test authors are 0.76 for decoding and 0.83 for comprehension.

\subsubsection{Developmental Spelling Assessment Screener}

The Developmental Screening Inventory ([DSI] Ganske, 2014) is an untimed, group administered spelling assessment composed of 20 words that increase in spelling knowledge complexity. Results of the test suggest what the student understands about letter-sound correspondences. The 20 words are grouped into four sections of five words each. The sections represent the four stages of spelling development (letter naming, within-word, syllable juncture, and derivational constancy) as described by Henderson \& Templeton (1986) and provides a measure of the child's orthographic knowledge (Ehri, 1993; Ganske, 1994, 2014). The test is administered one word at a time where the teacher pronounces the word, uses it in a sentence, and then pronounces it again. The student writes the word on their answer sheet and then waits for the teacher to say the next word. 
The DSI is scored by awarding one point for each correctly spelled word for a total score ranging from 0 to 20 . The assessed range in this study is 0 to 20 with 19 students attaining a score of 20. Two forms of the DSI are available with Form A used in the fall and Form B in the spring. Pearson- $r$ correlations for the five words comprising each of the four spelling stages as reported by the test author range from 0.97 to 0.99 while test-retest correlations range from 0.97 to 0.98 .

\subsubsection{Word Reading}

Word reading is assessed using the Test of Word Reading Efficiency-2 ([TOWRE] Torgesen, Wagner, \& Rashotte, 2014). The TOWRE consists of two subtests that determine a students' ability to efficiently read 1) sight-words (SWE) and 2) phonologically regular pseudo-words (PDE). Sight-word efficiency reflects the extent to which students have automatized regular words while pseudo-word reading is indicative of the student's ability to quickly apply what they understand about letter-sound correspondence to reading decodable non-words. The TOWRE is available in four forms with Forms A \& B used in this study. The test is administered individually to each student. For each subtest, the student has 45 seconds to read aloud increasingly complex words that are aligned in columns on the test page. The test administrator marks words read incorrectly with the raw score equal to the number of words pronounced correctly for each subtest. The maximum possible score is 66 for pseudo-word reading and 108 for sightword reading. In this study, the range of scores on the pseudo-word test (PDE) was 0 to 64 while the range on the sight-word test (SWE) was 0 to 94 . Test-retest reliability coefficients for the assessed age group equals 0.92 for the sight-word test and 0.87 for the pseudo-word test.

\subsubsection{Reading Fluency}

The assessment of reading fluency consisted of students individually reading aloud a curriculum-based measure (CBM). Students read the narrative passage for 3 minutes while being scored for reading miscues (omissions, insertions, mispronounced words, reversals and skipping a line) by the test administrator. If after 3 seconds students were unable to read a word it was counted as an error, and the student was told the word and directed to continue reading. Total time spent reading was recorded for those who finished in less than 3 minutes. Passages were administered in the fall and spring and ranged between 332 and 358 words in length and were measured for Lexile complexity using the Lexile Analyzer (MetaMetrics, 2016). All passages measured in the $700 \mathrm{~L}$ to $800 \mathrm{~L}$ range and are within the text complexity grade-bands identified by the Common Core (2010) as appropriate for third-grade readers $(420 \mathrm{~L}$ to $850 \mathrm{~L})$. Texts were also analyzed using Coh-Metrix (Graesser, McNamara, \& Kulikowich, 2011) and were all found to be high in narrativity, syntactic simplicity, word concreteness, referential and deep cohesion. Curriculum-based measures have been shown to be valid measures of reading competency (Fuchs, Fuchs, Hosp, \& Jenkins, 2001) 
that possess adequate reliability (Deno, 1985; Deno, Mirkin, \& Chiang, 1982; McGlinchey \& Hixson, 2004). The range of reading fluency scores for this group of students was 0 to 200 words-correct-per-minute. Reliability of the present data was determined using a split-half reliability test resulting in Pearson's $r$ ranging between 0.982 and 0.991 depending on the text.

\subsubsection{Assessment Administration}

All assessments were individually administered to students by their Project teacher. Teachers and coaches were instructed on the administration and scoring of each instrument early in foundational training. Assessments were introduced one at a time followed by in-class administration practice. Teachers were then required to administer the assessments to two students and then bring the completed assessments to class. Assessments were then blindly scored by both the instructor and student and compared for reliability. Students whose grading was not in complete agreement with that of the instructor were immediately remediated to correct the scoring error. Those teachers were then required to bring to class an additional set of assessments from two different students the following week to repeat the scoring procedure under the auspices of the instructor. After $100 \%$ agreement with the instructor, a sample of blind scores for both raters were returned to the researchers for another round of reliability checking. After training and reliability checking, teachers then administered all assessments to their remaining students. Because of the temporal distance between the assessment periods the administration training protocol was repeated in April as preparation for the May assessment period.

\section{Results}

This study reports first, the results of a project to improve teacher capacity of core reading content and second, changes in third-grade reading outcomes over a three-year period as measured by developmental spelling knowledge, pseudoand sight-word reading, and reading fluency. We begin by analyzing growth in teacher knowledge as measured by the LIKS.

\subsection{Research Question One}

Research question one asks if teachers' reading knowledge improved after participating in foundational training provided by the Project. Note the LIKS data reflects teachers participating in foundational training classes only and does not include those in advanced training. Table 2 shows the means and standard deviations of the pre- and posttest results for teacher knowledge from the decoding, comprehension, and total knowledge domains of the LIKS by Project year $(1,2$, $\& 3)$. A visual inspection shows that with the exception of Year 2 comprehension, all posttest means exceeded those of the pretest. The decoding subtest means increased from 14.6 to 18.1 in Year 1, from 15.5 to 19.1 in Year 2, and from 15.7 to 19.3 in Year 3. Comprehension test means changed from 21.9 to 24.8 in Year 1 while virtually no change was seen in Year 2 (23.83 to 23.87), with 
increases from 20.9 to 24.0 found in Year 3. Total knowledge means increased from 36.9 to 43.3 in Year 1, Year 2 increased from 39.3 to 42.9, while Year 3 increased from 36.6 to 43.1 . We conducted a series of paired-sample $t$-tests using a Bonferroni correction between pre- and posttest LIKS results to determine the statistical significance of change with effect size measured using Cohen's $d$ (Cohen, 1988). Results in Table 3 show that Year 1 teachers made significant improvement in decoding knowledge, $t(1,45)=7.2, p<0.001, d=0.93$, comprehension, $t(1$, $45)=7.76, p<0.001, d=0.59$, and total knowledge, $t(1,45)=9.35, p<0.001, d$ $=0.90$. Year 2 teachers showed statistically significant improvement in decoding

Table 2. Means, standard deviations, and standard errors for LIKS assessment of pre- and posttest decoding, comprehension, and total knowledge domains

\begin{tabular}{ccccccc}
\hline \multirow{2}{*}{ Variable } & \multicolumn{2}{c}{$\underline{\text { Year 1 }(n=46)}$} & \multicolumn{2}{c}{ Year 2 $(n=61)$} & \multicolumn{2}{c}{ Year 3 $(n=58)$} \\
\cline { 2 - 7 } & Mean(sd) & Std. Error & Mean $(s d)$ & Std. Error & Mean $(s d)$ & Std. Error \\
\hline Decoding & & & & & & \\
Pretest: & $14.61(3.82)$ & 0.39 & $15.47(4.25)$ & 0.34 & $15.66(3.53)$ & 0.39 \\
Posttest: & $18.14(3.72)$ & 0.38 & $19.09(4.71)$ & 0.38 & $19.33(4.38)$ & 0.48 \\
Comprehension & & & & & & \\
Pretest: & $21.86(5.32)$ & 0.43 & $23.83(5.37)$ & 0.42 & $20.89(5.82)$ & 0.51 \\
Posttest: & $24.81(4.96)$ & 0.41 & $23.87(5.34)$ & 0.42 & $23.98(4.72)$ & 0.41 \\
Total Knowledge & & & & & & \\
Pretest: & $36.88(6.51)$ & 0.68 & $39.30(8.03)$ & 0.65 & $36.60(7.50)$ & 0.93 \\
Posttest: & $43.33(7.92)$ & 0.82 & $42.92(8.71)$ & 0.70 & $43.12(7.73)$ & 0.96 \\
\hline
\end{tabular}

Note. Decoding subscale range is 0 to 32 ; comprehension subscale range is 0 to 43 . Total knowledge is a sum of the decoding and comprehension subscales for a range of 0 to 75 .

Table 3. Pre- to posttest change in LIKS scores by year and domain.

\begin{tabular}{ccc}
\hline Year/Domain & $t(d f)$ & $d$ \\
\hline $2014-15$ & $7.20(1,45)^{* * *}$ & 0.93 \\
Decoding & $7.76(1,45)^{* * *}$ & 0.59 \\
Comprehension & $9.35(1,45)^{* * *}$ & 0.90 \\
Total Knowledge & & \\
$2015-15$ & $9.94(1,60)^{* * *}$ & 0.81 \\
Decoding & $0.109(1,60)$ & - \\
Comprehension & $6.36(1,60)^{* * *}$ & 0.44 \\
Total Knowledge & & 0.94 \\
$2016-17$ & $8.06(1,57)^{* * *}$ & 0.59 \\
Decoding & $4.49(1,57)^{* * *}$ & 0.86 \\
Comprehension & $5.21(1,57)^{* * *}$ & \\
Total Knowledge &
\end{tabular}

Note. LIKS $=$ Literacy Instruction Knowledge Scale. ${ }^{* *} p<0.001 . d=$ Cohen's $d$. 
knowledge, $t(1,60)=9.94, p<0.001, d=0.81$, and total knowledge, $t(1,60)=$ $6.36, p<0.001, d=0.44$, with no significant gains found for comprehension. Year 3 teachers showed improvement in decoding knowledge, $t(1,57)=8.06, p$ $<0.001, d=0.94$, comprehension, $t(1,57)=4.49, p<0.01, d=0.59$, and total knowledge, $t(1,57)=5.21, p<0.001, d=0.86$.

\subsection{Research Question Two}

For each study year we measured spelling development, sight-word reading, pseudo-word reading, and reading fluency with each year representing an independent sample of students. Table 4 shows the means and standard deviations for the measured variables by year while Table 5 shows the bi-variate correlations. A close inspection of the study variables indicates some differences in the levels of fall achievement between years while spring scores appear to increase in years two and three beyond that of year one. Bi-variate correlations reveal moderate to large relationships between variables for each of the three years with relationships in years two and three appearing generally larger than those in year one.

Research question two asks the extent to which student reading outcomes changed over the three years of the Project. The Figure 3 bar graph shows the fall and spring means for each variable across the three study years. A visual inspection of the means shows first, that growth occurred in each of the four variables between fall and spring of each year. Developmental spelling means increased from 3.1 to 5.5 in Year 1 while in Year 2 it increased from 3.2 to 7.6, and in Year 3 means rose from 3.5 to 7.4. Pseudo-word reading means saw Year 1 rise from 13.9 to 18.0, Year 2 increase from 14.1 to 23.0 and Year 3 improve from 14.0 to 23.3. For sight-word reading Year 1 means increased from 40.0 to 48.5 while Year 2 rose from 39.4 to 55.0, and Year 3 increases grew from 40.7 to 55.2. Increase in reading fluency can also be seen as Year 1 rose from 60.7 to 73.3, Year 2 began at 63.2 and then rose to 86.6, and Year 3 improved from 60.3 to 85.7. The second observation from Figure 3 is that the spring means for Years 2 and 3 consistently exceeded those for the spring of Year 1. Spelling development in spring of Year 1 was 5.5 compared to 7.6 and 7.4 in the spring of Years 2 and 3 respectively. The spring mean for Year for pseudo-word reading was 18.0 and increased to 23.0 in Year 2 and 23.4 in Year 3. The same trend can be seen in sight-word reading where the Year 1 spring mean is 48.5, while the Year 2 mean is 55.0 and Year 3 is 55.2. Finally, reading fluency shows a spring of Year 1 mean equal to 73.3 which increased to 86.6 and 85.7 respectively for Years 2 and 3. Our next step is to determine the statistical significance of these observed changes.

To investigate the differences in the outcome measures between the three years, a one-way analysis of covariance (ANCOVA) was utilized for each outcome. The ANCOVA featured year as a three-level independent factor (2015, 2016, and 2017) and the fall measure of the outcome (assessments) as the covariate resulting in the following equation: 
Table 4. Third-grade means and standard deviations for reading outcome variables by year.

\begin{tabular}{ccccccc}
\hline \multirow{2}{*}{ Variable } & \multicolumn{2}{c}{ Year 1 $(n=392)$} & \multicolumn{2}{c}{ Year 2 $(n=410)$} & \multicolumn{2}{c}{ Year 3 $(n=460)$} \\
\cline { 2 - 7 } & Fall & Spring & Fall & Spring & Fall & Spring \\
\hline Developmental Spelling & $3.07(2.02)$ & $5.51(2.57)$ & $3.15(1.38)$ & $7.59(3.16)$ & $3.48(1.33)$ & $7.37(2.82)$ \\
Pseudo-Word Reading & $13.94(4.43)$ & $17.95(5.34)$ & $14.09(6.39)$ & $22.96(7.57)$ & $13.99(5.89)$ & $23.40(8.37)$ \\
Sight-Word Reading & $40.01(8.26)$ & $48.50(7.98)$ & $39.39(8.70)$ & $55.00(10.13)$ & $40.67(8.18)$ & $55.24(8.86)$ \\
Reading Fluency & $60.71(15.79)$ & $73.31(17.15)$ & $63.16(22.35)$ & $86.56(24.04)$ & $60.32(21.59)$ & $85.72(27.36)$ \\
\hline
\end{tabular}

Note. Differences from fall to spring within year are all statistically significant at $p<0.001$.

Table 5. Bivariate correlations for reading outcome variables by year.

\begin{tabular}{|c|c|c|c|c|c|c|c|c|}
\hline & 1 & 2 & 3 & 4 & 5 & 6 & 7 & 8 \\
\hline \multicolumn{9}{|l|}{ Year 1} \\
\hline 1. Spelling Fall & 1 & & & & & & & \\
\hline 2. Spelling Spring & $0.764^{* *}$ & 1 & & & & & & \\
\hline 3. Pseudo-word Fall & $0.224^{* *}$ & $0.191^{* *}$ & 1 & & & & & \\
\hline 4. Pseudo-word Spring & $0.281^{* *}$ & $0.303^{* *}$ & $0.727^{\star *}$ & 1 & & & & \\
\hline 5. Sight-word Fall & $0.289^{* *}$ & $0.334^{* *}$ & $0.686^{* *}$ & $0.527^{\star *}$ & 1 & & & \\
\hline 6. Sight-word Spring & $0.350^{* *}$ & $0.357^{\star *}$ & $0.586^{* *}$ & $0.707^{\star *}$ & $0.736^{* *}$ & 1 & & \\
\hline 7. Fluency Fall & $0.407^{* *}$ & $0.373^{* *}$ & $0.416^{* *}$ & $0.412^{\star *}$ & $0.446^{* *}$ & $0.495^{* *}$ & 1 & \\
\hline 8. Fluency Spring & $0.424^{* *}$ & $0.411^{* *}$ & $0.497^{\star *}$ & $0.624^{\star *}$ & $0.653^{* *}$ & $0.653^{* *}$ & $0.731^{* *}$ & 1 \\
\hline Year 2 & $\underline{1}$ & $\underline{2}$ & $\underline{3}$ & $\underline{4}$ & $\underline{5}$ & $\underline{6}$ & $\underline{7}$ & $\underline{8}$ \\
\hline 1. Spelling Fall & 1 & & & & & & & \\
\hline 2. Spelling Spring & $0.534^{* *}$ & 1 & & & & & & \\
\hline 3. Pseudo-word Fall & $0.299^{* *}$ & $0.385^{* *}$ & 1 & & & & & \\
\hline 4. Pseudo-word Spring & $0.391^{* *}$ & $0.433^{* *}$ & $0.583^{* *}$ & 1 & & & & \\
\hline 5. Sight-word Fall & $0.282^{* *}$ & $0.410^{* *}$ & $0.377^{\star *}$ & $0.497^{\star *}$ & 1 & & & \\
\hline 6. Sight-word Spring & $0.330^{* *}$ & $0.440^{* *}$ & $0.494^{* *}$ & $0.608^{* *}$ & $0.579^{* *}$ & 1 & & \\
\hline 7. Fluency Fall & $0.413^{* *}$ & $0.509^{* *}$ & $0.514^{* *}$ & $0.572^{* *}$ & $0.651^{\star *}$ & $0.571^{\star *}$ & 1 & \\
\hline 8. Fluency Spring & $0.436^{* *}$ & $0.575^{* *}$ & $0.430^{* *}$ & $0.595^{\star *}$ & $0.594^{* \star}$ & $0.632^{\star *}$ & $0.749^{* *}$ & 1 \\
\hline Year 3 & $\underline{1}$ & $\underline{2}$ & $\underline{3}$ & $\underline{4}$ & $\underline{5}$ & $\underline{6}$ & $\underline{7}$ & $\underline{8}$ \\
\hline 1. Spelling Fall & 1 & & & & & & & \\
\hline 2. Spelling Spring & $0.678^{\star *}$ & 1 & & & & & & \\
\hline 3. Pseudo-word Fall & $0.472^{\star *}$ & $0.534^{\star *}$ & 1 & & & & & \\
\hline 4. Pseudo-word Spring & $0.504^{* *}$ & $0.554^{* *}$ & $0.723^{* *}$ & 1 & & & & \\
\hline 5. Sight-word Fall & $0.445^{\star *}$ & $0.458^{\star *}$ & $0.495^{\star *}$ & $0.576^{* *}$ & 1 & & & \\
\hline 6. Sight-word Spring & $0.429^{* *}$ & $0.502^{* *}$ & $0.520^{* *}$ & $0.663^{* *}$ & $0.712^{* *}$ & 1 & & \\
\hline 7. Fluency Fall & $0.518^{\star *}$ & $0.502^{* \star}$ & $0.523^{* *}$ & $0.613^{* *}$ & $0.710^{* \star}$ & $0.667^{\star *}$ & 1 & \\
\hline 8. Fluency Spring & $0.496^{* *}$ & $0.460^{* *}$ & $0.488^{* *}$ & $0.570^{* *}$ & $0.593^{\star *}$ & $0.679^{* *}$ & $0.665^{\star *}$ & 1 \\
\hline
\end{tabular}

Note. Spelling = Development Spelling Assessment-Screener; Pseudo-word = pseudo-word reading; Sight-word = sight word reading; Fluency = oral reading fluency. ${ }^{* *} p<0.01$ (2-tailed). 


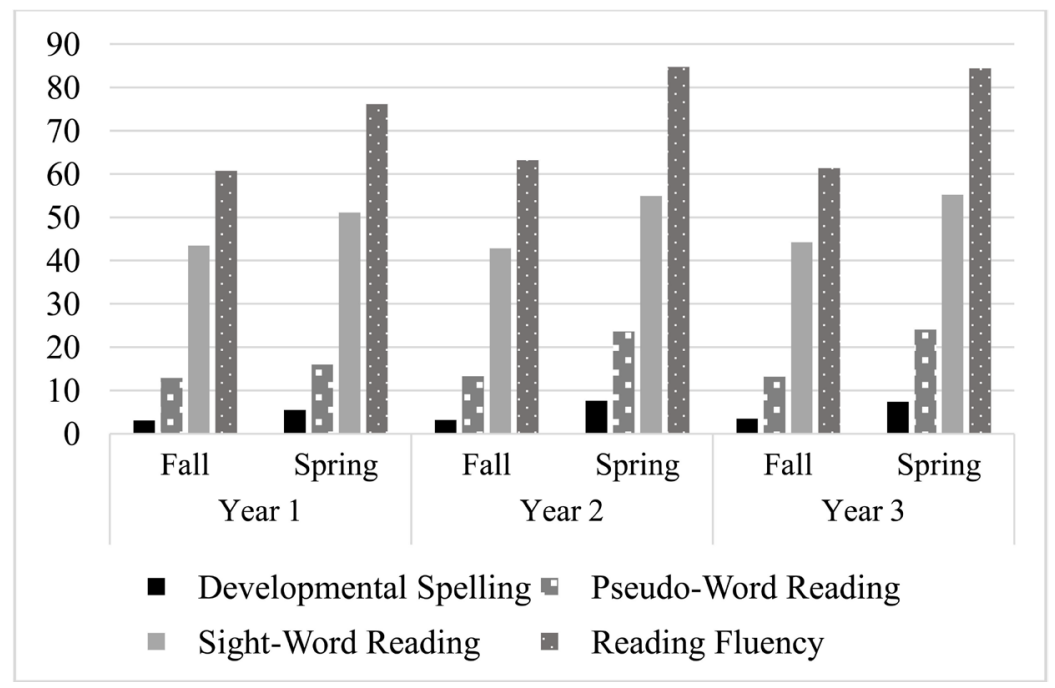

Figure 3. Means of the measured variables by time of year by year.

$$
\begin{gathered}
Y_{i j}=\mu+\tau_{i}+\beta_{i} X_{i}+\varepsilon_{i j} \\
\left(Y_{i j}=\text { Spring Measure; } \tau_{i}=\text { Year; } \beta_{i} X_{i}=\text { Fall Measure }\right)
\end{gathered}
$$

Utilizing the fall measure as a covariate in each of the models controls for any variability between the years resulting from the pretest (Fall measure). The ANCOVA controls for any differences in the outcomes (spring measure) that may be attributable to the fall measure. ANCOVA is an efficient method for isolating a treatment effect and the use of pretest scores is an effective covariate when the purpose of the model is to examine post-test variability (Yang \& Tsiatis, 2001). In practical terms, the ANCOVA adjusts the data such that the different starting points (fall measures) do not impact the observed differences in the spring measures. The slopes shown in Table 6 represent the within year comparison (fall to spring). In all years the slopes are statistically significant $(p<$ 0.001 ) indicating a significant increase in the spring scores compared to those from the fall.

\subsection{Research Question Three}

Research question three asks if the rate of student learning on the measured variables changed by year? In other words, for each of the measured variables did students acquire the same amount of learning each year or were some years more productive than others? It may be inferred that the greater the value of the slope estimate the greater the rate or magnitude of learning. Equality of slopes by year would indicate an equal amount of learning took place while statistically significant differences between the slopes would indicate student learning differed. Figure 4 plots the mean growth by variable while Figure 5 plots the slope coefficient estimates by year for each of the four student outcomes.

To test the hypothesis of equality of slopes by year: $H_{0}: \beta_{1}=\beta_{2}=\beta_{3}$, the procedure suggested by the UCLA Institute for Digital Research and Learning (Introduction to SAS) was followed. First the data were recoded using STATA 


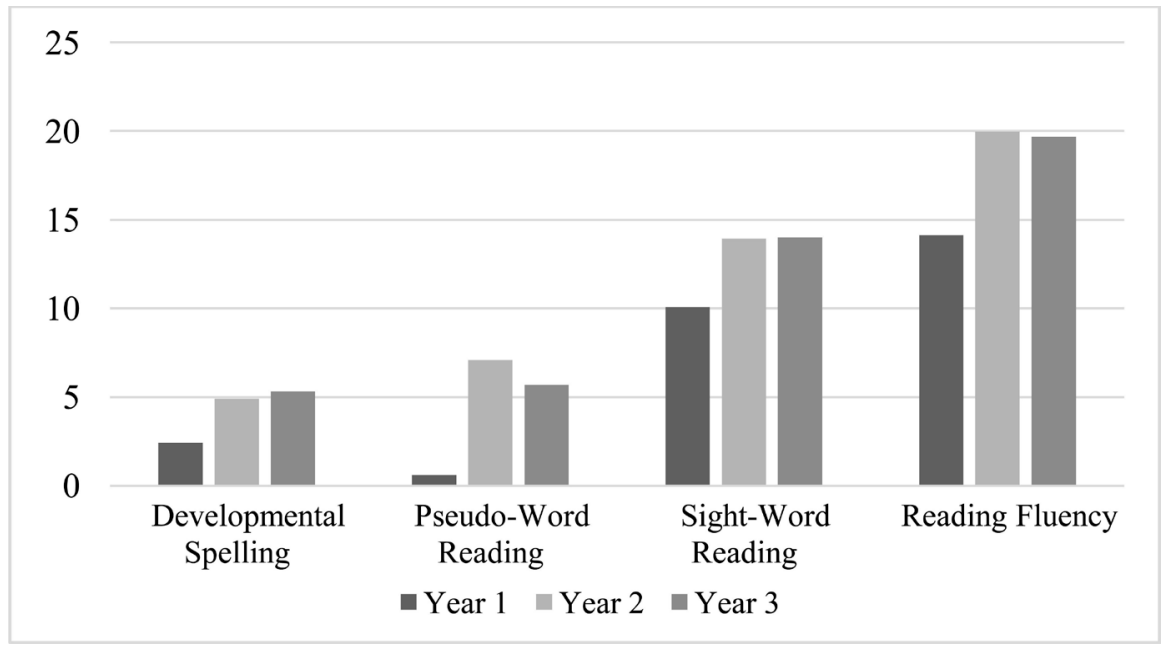

Figure 4. Mean growth by year by variable.

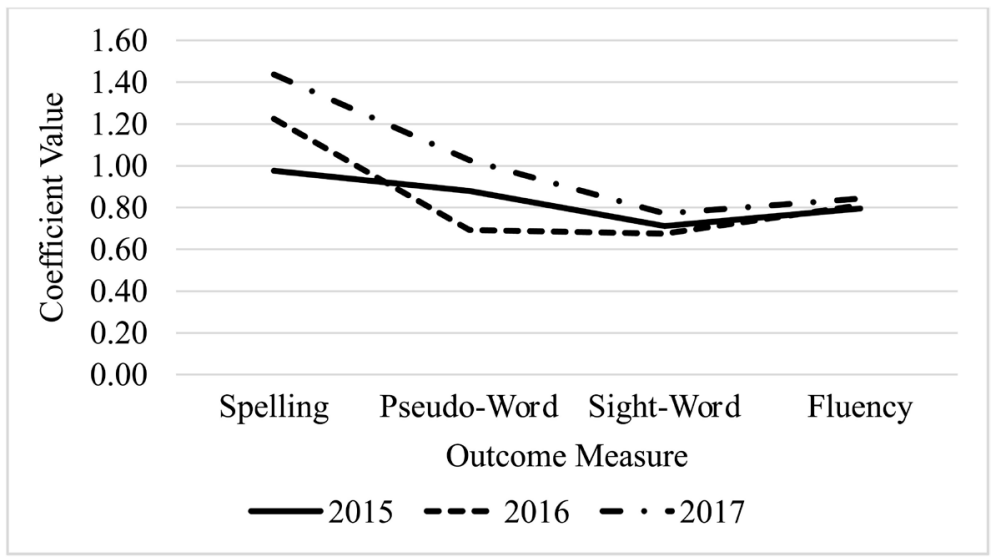

Figure 5. Slope coefficient estimates by year by measure.

software to construct a dummy variable for year. Next, new variables were created to estimate the interaction of the year ${ }^{\star}$ fall measure. The new terms were then used in a dummy regression to predict the spring measure (outcome). This resulted in the equation:

$$
Y_{i j}=\beta_{0}+\beta_{1} X_{1}+\beta_{2} X_{2}+\beta_{3} X_{1} X_{2}+\varepsilon_{i j}
$$

(Spring Measure, $\beta_{1} X_{1}=$ Dummy variable for year, $\beta_{2} X_{2}=$ Fall measure, and $\beta_{3} X_{1} X_{2}=$ Interaction of Year${ }^{\star}$ Fall measure)

When the results indicated overall model significance ( $F$-test), pairwise comparisons were estimated to investigate the simple factor level effects. The pairwise comparisons were estimated in a method similar to the overall model but the dummy term was limited to two years rather than three. When the interaction term comprised of the two years and the fall measure was significant, it is reported as a significant simple effect ( $t$-statistic.) Table 6 reports the results of this statistical testing to determine differences between years (rate of magnitude of yearly increase). Figure 5 plots the regression coefficient by variable by year. Results for spelling knowledge show that the slope in 2015 of 0.975 was less than 
Table 6. Unstandardized slope coefficient estimates from analysis of covariance (ANCOVA) by variable by spring of year.

\begin{tabular}{ccccc}
\hline Year & Spelling $\left(R^{2}\right)^{1}$ & Pseudo Word $\left(R^{2}\right)^{2}$ & Sight Word $\left(R^{2}\right)^{3}$ & Fluency $\left(R^{2}\right)^{3}$ \\
\hline 2015 & $0.975(0.47)$ & $0.878(0.47)$ & $0.711(0.54)$ & $0.795(0.53)$ \\
2016 & $1.225(0.56)$ & $0.691(0.58)$ & $0.674(0.34)$ & $0.810(0.56)$ \\
2017 & $1.437(0.37)$ & $1.027(0.40)$ & $0.771(0.51)$ & $0.843(0.44)$ \\
\hline
\end{tabular}

Notes. All $R^{2}$ values are significant at $p<0.001 .{ }^{1}$ Spelling slope coefficient for the three years are statistically different from each other, $F(2,1257)=12.6, p \leq 0.001$; ${ }^{2}$ Pseudo-Word slope coefficients for the three years are statistically different from each other, $F(2,1256)=16.1, p \leq 0.001$; ${ }^{3}$ Slope coefficients for the three years are not statistically different from each other.

those for both 2016 (slope $=1.225),(t(3,799)=2.55, p=0.001)$ and 2017 (slope $=1.437),(t(3,848)=5.65, p \leq 0.001)$ while the 2016 slope was statistically equal to that of $2017(t(3,867)=-0.178, p=0.075)$. In other words, the magnitude of change for spelling knowledge in 2016 was $26 \%$ over 2015, while the 2017 magnitude was $47 \%$ higher than 2015. For pseudo-word reading the 2015 slope of 0.878 exceeded that of 2016 (slope $=1.225),(t(3,798)=2.65, p=0.008)$ while the 2017 slope of 1.027 exceeded those of $2015(t(3,848)=2.17, p=0.029)$ and $2016(t(3,866)=5.09, p \leq 0.001)$. For pseudo-word reading the magnitude of growth between 2015 and 2016 dropped by $21.3 \%$ while 2017 was $17 \%$ greater than 2015. Analysis of the slope coefficients for sight-word reading and reading fluency resulted in no between-year differences meaning the magnitude of learning for each year was similar.

\section{Discussion}

The Project was guided by a learning to improve framework suggesting intensive professional development combined with effective literacy coaching may facilitate knowledge-to-practice transfer of effective classroom instruction that can improve student outcomes. Our first research question asked to what extent did teachers grow in their declarative reading knowledge as a result of one year of Project training? With the exception of Year 2 comprehension, results showed that teachers in each of the three years of the Project increased their knowledge of decoding and comprehension with moderate to large effects as measured by a standardized instrument of reading knowledge. With the exception of Year 2 comprehension, which yielded a moderate effect size, decoding, comprehension, and total knowledge gains all reflected large to very large effect sizes. The Project curriculum engaged in by teachers consisted of 90 hours of classroom training distributed over the course of a school year, while about half of first-year teachers volunteered for a second year that brought their total training hours to 180 . Throughout the Project curriculum designers used a formative approach which allowed for carefully considered adjustments to enhance the learning and utility of the training content. This approach provided curriculum designers the space to learn and improve based on teacher and instructor feedback and to make use of information gained from student outcomes. In Year 2 for example, the curri- 
culum was moderated to reflect greater emphasis on phonological awareness and letter-feature analysis. While this may have contributed to the decline in Year 2 comprehension gains seen on the teacher knowledge instrument, it may have also improved developmental spelling scores in the two succeeding years. The curriculum was adjusted in preparation for Year 3 to include additional comprehension material which was reflected in end of Year 3 LIKS increases in comprehension knowledge. Also, in the second year additional emphasis was put on the use of the Developmental Spelling Inventory (DSA) as a diagnostic tool to clearly understand what students understood and needed to learn regarding letter-sound correspondence. In the second and third years of training teachers were taught to use the DSA feature inventories (letter-name, within-word, syllable juncture, and derivational constancy) as a tool to diagnose and group students for differentiated word work instruction.

Our results for research question two are reported in Table 6 and show large regression coefficients for each measured outcome across all three years. A study by Paige et al., (2019) used path analysis to model the contribution of developmental spelling and found it contributed significant, unique variance, beyond even reading fluency, to achievement on the end-of-year state reading assessment. This finding provides evidence that developmental spelling is critical to reading achievement. The results of this study show that end of Year 1 developmental spelling means were equal to 5.51 (2.57) showing that as a group, students were exiting the letter-naming stage and entering the within-word spelling stage. While this level of spelling understanding may reflect appropriate development for end-of-year first-grade students, it is inadequate for third-graders who are likely to receive little phonics instruction in fourth-grade and beyond. In Year 1 we also saw pseudo- and sight-word reading attainment scores of 17.95 (5.34) and 48.50 (7.98) respectively, both of which are commensurate with the $14^{\text {th }}$ percentile. End-of-first-year reading fluency was 73.31 (17.50), a score approximating the $23^{\text {rd }}$ percentile on the Hasbrouck \& Tindal (2006) reading norms. In total these measures suggest a group of students with an insufficient understanding of the sound structure of words that resulted in poor word reading and languid reading fluency.

Results for the spring of years two and three saw spelling development increase to 7.59 (3.16) and 7.37 (2.82) respectively, putting the group mean well into the within-word (WW) stage. The WW stage reflects an understanding of letter features that includes long vowels (VCe), r-controlled vowels (e.g., air, birch, spur), other common long- and short-vowel patterns such as long /e/, /i/, /o/, and /u/ (e.g., sea, high, boat, blew, clue). It also reflects growing understanding of complex consonant patterns such as /scr/, /spl/, /squ/, and /thr/, and silent consonant patterns like gn/kn (gnarl, knack), mb/wr (limb, wring), as well as abstract vowel understanding as in /oi/ (joint), /ou/ (foul), /au/ (fraud), /ä/ /ör/ (swat and warp). Pseudo- and sight-word reading also saw significant increases in years two and three to $22.95(7.57) / 23.40(8.37)$ and $55.00(10.13) / 55.24(8.86)$ re- 
spectively. These results represent attainment at the 25th (pseudo-word) and $32^{\text {nd }}$ percentiles (sight-word) reflecting increases from end-of-year-one percentiles at the $14^{\text {th }}$ and $23^{\text {rd }}$ percentiles respectively. While reading accumaticity (CWPM) at the end of year one was at the $23^{\text {rd }}$ percentile, year two and three results showed scores of 86.56 (24.04) and 85.72 (27.36) respectively, reflecting attainment at approximately the $43^{\text {rd }}$ percentile for both. Although we do not have a direct measure of classroom reading instruction, we take the year 2 and 3 increases across the measured variables as indirect evidence that instruction improved. We think it is unlikely that given the large sample sizes across the three years that students independently improved with no instructional input.

Beyond quantifying the descriptive changes occurring in all four of the reading outcomes, our third research question explored whether the magnitude of learning differed by year. Our analysis of covariance (ANCOVA) results revealed that the regression slopes were significantly different across the three years for two of the reading outcome variables. While the plots in Figure 4 for spelling development and pseudo-word reading show clear differences in the magnitude of growth between years, those for sight-word reading and fluency clearly do not. We interpret the between-year increases in the magnitude of spelling knowledge growth as evidence that students learned at increasingly faster rates. While we cannot make a causal claim, we interpret this as suggesting teachers became increasingly proficient with instructional practices that encourage letter-feature development in students. As pseudo-word reading reflects the ability of students to apply their letter-feature knowledge to decode words, the increases in 2017 over 2015 suggests growth in the magnitude of student learning. The 2014 to 2015 reduction in the regression coefficient for pseudo-word learning is difficult to explain as there could be numerous reasons. The regression coefficients for sight-word reading and fluency also show significant growth for each year, although differences suggesting increasingly faster between-year growth were not found.

Our perspective of learning to improve emerges from a quality improvement paradigm suggesting that a process for improvement of core reading instruction can ultimately lead to enhanced instruction and predictable growth in student outcomes. Quality improvement (Deming, 2000; Shewhart, 1980) is a system that begins with the identification of quality measures, that is, the activities that occur within the instructional process that contribute to its' ultimate quality. For example, one quality measure is teacher core knowledge of reading that was addressed in the present study. Other quality indicators likely exist which act to produce improved student outcomes. Some of these may include the amount of time teachers are actually engaged in teaching reading, the efficient use of instructional time, word-work quality, the extent to which instruction is differentiated to account for learner differences, and the regular use of formative and diagnostic assessments to measure growth of critical reading sub-skills (Black \& William, 1998). Other indicators include the amount of time students spend ac- 
tually reading appropriate connected texts, the complexity of text that students are asked to read, the amount and quality of teacher feedback provided to students, the materials teachers use to implement instruction, and the fidelity with which teachers implement a teaching and learning cycle. We suggest it is reasonable to expect that teachers differ in the quality with which they implement these and other instructional indicators and that these differences account for common variation that affects student outcomes. It follows then that determining which indicators account for the greatest variation in student learning, and then bringing them into statistical control may lead to reading achievement gains. We posit that a continuous quality improvement process (which implies it is guided by appropriate measurement) can provide a school with a proven, reliable, and predictable process that puts it in control of instructional improvement and student outcomes.

\section{Primary Contribution of the Research}

This study contributes to the research base in four ways. First, the study shows that improving in-service teacher knowledge of core reading and pedagogy practices is possible through a focused curriculum. Second, the results show that it takes time for teacher knowledge and practice to change. In other words, changes in student outcomes do not come quickly as teacher must first become comfortable with new understandings about reading and changes to their pedagogy. Third, the study shows that improving decoding knowledge at scale, as indicated by the statistically significant increases in spelling development and pseudo-word reading across 63 schools and 165 teachers, is possible. Fourth, the similar results in Years 2 and 3 effectively represents a replication of the Project that provides evidence suggesting the efficacy of the curricular focus and content taken by Project designers.

\section{Conclusion}

It remains a question whether or not additional or different Project training content would have improved reading outcomes beyond those found in the present study. Also unknown is the effect of the advanced year of training on teacher practice and student outcomes. From an anecdotal perspective, teachers participating in the second year of the Project reported an increased understanding of the diagnostic assessments and how to leverage those results to improve and differentiate their instruction. From a teacher preparation perspective, the Project results suggest that improvement of reading instruction is intensive, hard work that must have at its foundation the correct curriculum that teachers perceive to be worth learning. Improvement must also involve knowledgeable individuals in the form of training instructors and literacy coaches to support and guide teacher learning and classroom implementation. What is critical is that at some point teachers begin to see improvement in their students that suggests their effort is worth their trouble. It is in these moments when teachers be- 
gin to understand, as Deming (1980) suggests, that first knowing what to do and then doing it well is critical to helping their students become better readers.

Given the reviewed research suggesting teachers are poorly prepared to teach reading to students at-risk for reading failure, combined with data showing too many students are underachieving in reading, leads to the consideration that the current reading teacher preparation model is insufficient (Licklider, 1997). Much as a medical student who just received an M.D. degree is not ready to practice without several years of residency training, graduation from a teacher preparation program can provide at best, a start at becoming a skilled reading teacher. It may be that becoming competent in the practice of reading instruction requires much more than preparation programs can provide under the current model. Long-term and consistently poor national and state-level reading results support the notion that post-certification PD is not improving reading outcomes. As Project implementation began we were surprised at the poor level of core reading knowledge across one of the country's great city school districts. From the central office and senior administrator level down to the building level, deep literacy knowledge was universally absent. Even more problematic was the presence of instructional ideas that were at odds with what we know about how humans read and how best to teach its acquisition. Our efforts suggest to us that teachers of students at-risk for reading failure are in need of long-term, high-level "residency" training under highly knowledgeable coaches employing best practices within a proven quality improvement system. While the question remains of how best to deliver such training we suggest that the model presented in the present study is a beginning.

\section{Limitations}

Our results are limited by the absence of a randomized control trial to control for possible confounds and alternate explanations to the study results. This leaves open the possibility that other factors could explain both teacher training outcomes and the increases in student outcomes. This study is also limited by an inability to measure the incremental contribution of the second year of teacher training in the Project which we think may contribute to increase seen in student outcomes. The study design involved three independent cross sections of students that prohibited the tracking of within-student results across the three years. The study design was also not able to account for third-grade students in the study sample who had been previously instructed by Project teachers in either the first- or second-grade, or in both grades. It is entirely possible that an enhanced effect of the Project was experienced by students who received prior instruction from one or two Project teachers. Our study design only allowed the gathering of data from teachers enrolled in Project training. This meant we were unable to track individual Project teachers across the three years of the study, which could have provided valuable insight into teacher growth. We were unable to adequately document changes in classroom instruction. Such data would have 
allowed the measurement of change in teacher practice and modeling of its effect on student outcomes. In all, our study reflects the challenges of working within school districts where the desire for quickly improved outcomes on state assessments can be intense and the will and discipline to implement well-designed studies that can rigorously answer important questions is often lacking.

\section{Future Research}

Our results suggest research into the development of a continuous improvement system that can measure, analyze, and improve the indicators found to predict significant variance in reading instruction is needed. Much of the focus of reading research has been on the specification of the cognitive processes involved in reading and instructional strategies that facilitate growth in sub-processes such as phonological awareness, letter-sound learning, fluency, vocabulary, and comprehension. Much less is known about how these strategies work coherently within a system of instruction whose objective is to get every student to at least, minimum levels of reading achievement that can facilitate academic success. This is an ambitious task that has yet to resonate on a general basis across the research community and school districts. If NAEP and state accountability results are accepted as evidence of poor reading, we suggest it is time to move in the direction of the quality of improvement of reading instruction.

\section{Conflicts of Interest}

The authors declare no conflicts of interest regarding the publication of this paper.

\section{References}

Anderson, R. C., Hiebert, E. H., Wilkinson, I. A. G., \& Scott, J. (1985). Becoming a Nation of Readers: The Report of the Commission on Reading. Washington DC: National Institute of Education.

Applegate, A. J., \& Applegate, M. D. (2004). The Peter Effect: Reading Habits and Attitudes of Teacher Candidates. The Reading Teacher, 57, 554-563.

Atteberry, A., \& Bryk, A. (2011). Analyzing Teacher Participation in Literacy Coaching Activities. The Elementary School Journal, 112, 356-382. https://doi.org/10.1086/661994

Bean, R. M., Swan, A. L., \& Knaub, R. (2003). Reading Specialists in Schools with Exemplary Reading Programs: Functional, Versatile, and Prepared. The Reading Teacher, 56, 446-455.

Biancarosa, G., Bryk, A. S., \& Dexter, E. R. (2010). Assessing the Value-Added Effects of Literacy Collaborative Professional Development on Student Learning. Elementary School Journal, 111, 7-34. https://doi.org/10.1086/653468

Binks-Cantrell, E., Washburn, E. K., Joshi, R. M., \& Hougen, M. (2012). Peter Effect in the Preparation of Reading Teachers. Scientific Studies of Reading, 16, 526-536. https://doi.org/10.1080/10888438.2011.601434

Black, P., \& William, D. (1998). Assessment and Classroom Learning. Assessment in Education: Principles, Policy, \& Practice, 5, 7-74. 
https://doi.org/10.1080/0969595980050102

Blair, T. R., Rupley, W. H., \& Nichols, W. D. (2007). The Effective Teacher of Reading: Considering the "What" and "How" of Instruction. Reading Teacher, 60, 432-438. https://doi.org/10.1598/RT.60.5.3

Blank, R. K., \& de las Alas, N. (2009). Effects of Teacher Professional Development on Gains in Student Achievement. Washington DC: Council of Chief State School Officers. http://ccsso.org/Documents/2009/Effects_of_Teacher_Professional_2009.pdf

Bryk, A. S. (2014). 2014 AERA Distinguished Lecture: Accelerating How We Learn to Improve. Educational Researcher, 44, 467-477. https://doi.org/10.3102/0013189X15621543

Bush, R. N. (1984). Effective Staff Development in Making Schools More Effective: Proceedings of Three State Conferences. San Francisco, CA: Far West Laboratory. http://files.eric.ed.gov/fulltext/ED249576.pdf

Cohen, D. K. (1990). A Revolution in One Classroom: The Case of Mrs. Oublier. Educational Evaluation and Policy Analysis, 12, 311-329. https://doi.org/10.3102/01623737012003311

Cohen, D. K., \& Hill, H. C. (2001). Learning Policy: When State Education Reform Works. New Haven, CT: Yale University Press. https://doi.org/10.12987/yale/9780300089479.001.0001

Cohen, D. K., Raudenbush, S., \& Ball, D. (2000). Resources, Instruction and Research. A Working Paper from the Center for Teaching Policy.

Cohen, J. (1988). Statistical Power Analysis for the Behavioral Sciences (2nd ed.). Hillsdale, NJ: Erlbaum.

Corcoran, T. B., McVay, S., \& Riordan, K. (2003). Getting It Right: The MISE Approach to Professional Development. CPRE Research Report Series RR-55.

https://doi.org/10.12698/cpre.2003.rr55

https://repository.upenn.edu/cpre_researchreports/42/

Cornett, J., \& Knight, J. (2009). Research on Coaching. In J. Knight (Ed.), Coaching: Approaches and Perspectives (pp. 192-216). Thousand Oaks, CA: Corwin Press.

Darling-Hammond, L., Wei, R. C., Andree, A., Richardson, N., \& Orphanos, S. (2009). Professional Learning in the Learning Profession: A Status Report on Teacher Development in the United States and Abroad. Oxford, OH: National Staff Development Council.

Davis, M. H., McPartland, J. M., Pryseski, C., \& Kim, E. (2018). The Effects of Coaching on English Teachers' Reading Instruction Practices and Adolescent Students' Reading Comprehension. Literacy Research and Instruction, 57, 255-275.

https://doi.org/10.1080/19388071.2018.1453897

Deming, W. E. (2000). Out of the Crisis. Cambridge, MA: MIT Press.

Deno, S. L. (1985). Curriculum-Based Measurement: The Emerging Alternative. Exceptional Children, 52, 219-232. https://doi.org/10.1177/001440298505200303

Deno, S. L., Mirkin, P. K., \& Chiang, B. (1982). Identifying Valid Measures of Reading. Exceptional Children, 49, 36-45. https://doi.org/10.1177/001440298204900105

Desimone, L. M. (2009). Improving Impact Studies of Teachers' Professional Development: Toward Better Conceptualizations and Measures. Educational Researcher, 38, 181-199. https://doi.org/10.3102/0013189X08331140

Desimone, L. M., Porter, A. C., Garet, M. S., Yoon, K. S., \& Birman, B. F. (2002). Effects on Professional Development on Teachers' Instruction: Results from a Three-Year Longitudinal Study. Educational Evaluation and Policy Analysis, 24, 81-112. 


\section{https://doi.org/10.3102/01623737024002081}

Dole, J. A. (2004). The Changing Role of the Reading Specialist in School Reform. The Reading Teacher, 57, 462-471.

Dorph, R., Goldstein, D., Lee, S., Schneider, L, K., \& Venkatsesan, S. (2007). The Status of Science Education in the Bay Area: Research Brief. Berkeley, CA: Lawrence Hall of Science, University of California.

Ehri, L. C. (1993). How English Orthography Influences Phonological Knowledge as Children Learn to Read and Spell. In R. J. Scales (Ed.), Literacy and Language Analysis (pp. 21-43). Hillsdale, NJ: Lawrence Erlbaum Associates.

Elmore, R. F. (2002). Bridging the Gap between Standards and Achievement: The Imperative for Professional Development in Education. Washington DC: Albert Shanker Institute.

Ermeling, B. (2009). Tracing the Effects of Teacher Inquiry on Classroom Practice. Teaching and Teacher Education, 26, 377-388. https://doi.org/10.1016/j.tate.2009.02.019

Feldman, J., Schneck, A., Feighan, K., Coffey, D., \& Rui, N. (2011). Memphis Striving Readers Project, Evaluation Report Year 4. Research for Better Schools \& RMC Research Corporation.

Flesch, R. (1955). Why Johnny Can't Read. New York: HarperCollins.

Foorman, B., Beyler, N., Borradaile, K., Coyne, M., Denton, C. A., Dimino, J. et al. (2016). Foundational Skills to Support Reading for Understanding in Kindergarten through 3rd Grade (NCEE 2016-4008). Washington DC: National Center for Education Evaluation and Regional Assistance (NCEE), Institute of Education Sciences, U.S. Department of Education.

French, V. W. (1997). Teachers Must Be Learners, too: Professional Development and National Teaching Standards. NASSP Bulletin, 81, 38-44. https://doi.org/10.1177/019263659708158507

Fuchs, L. S., Fuchs, D., Hosp, M. K., \& Jenkins, J. R. (2001). Oral Reading Fluency as an Indicator of Reading Competence: A Theoretical, Empirical, and Historical Analysis. Scientific Studies of Reading, 5, 239-256. https://doi.org/10.1207/S1532799XSSR0503_3

Gamse, B. C., Jacob, R. T., Horst, M., Boulay, B., \& Unlu, F. (2008). Reading First Impact Study Final Report (NCEE 2009-4038). Washington DC: National Center for Education Evaluation and Regional Assistance, Institute of Education Sciences, U.S. Department of Education.

Ganske, K. (1994). Developmental Spelling Analysis: A Diagnostic Measure for Instruction and Research. Unpublished Doctoral Dissertation. Charlottesville, VA: University of Virginia.

Ganske, K. (2014). Word Journeys: Assessment-Guided Phonic, Spelling, and Vocabulary Instruction (2nd ed.). New York: The Guilford Press.

Garet, M. S., Cronen, S., Eaton, M., Kurki, A., Ludwig, M., Jones, W. et al. (2008). The Impact of Two Professional Development Interventions on Early Reading Instruction and Achievement (NCEE Report 2008-4031). Washington, DC: National Center for Educational Evaluation and Regional Assistance, Institute of Education Sciences.

Garet, M. S., Porter, A., Desimone, L., Birman, B., \& Yoon, K. S. (2001). What Makes Professional Development Effective? Results from a National Sample of Teachers. American Educational Research Journal, 38, 915-945. https://doi.org/10.3102/00028312038004915

Goldhaber, D., \& Anthony, E. (2007). Can Teacher Quality Be Effectively Assessed? National Board Certification as a Signal of Effective Teaching. Review of Economics and 
Statistics, 89, 134-150. https://doi.org/10.1162/rest.89.1.134

Graesser, A. C., McNamara, D. S., \& Kulikowich, J. M. (2011). Coh-Metrix: Providing Multilevel Analysis of Text Characteristics. Educational Researcher, 40, 223-234. https://doi.org/10.3102/0013189X11413260

Gulamhussein, A. (2013). Teaching the Teachers: Effective Professional Development in the Era of High Stakes Accountability. National School Board Association, Center for Public Education.

http://conference.ohioschoolboards.org/2017/wp-\%20content/uploads/sites/17/2016/0 7/1pm111317A114Job-embedPD.pdf

Harris, D. N., \& Sass, T. R. (2007). Teacher Training, Teacher Quality, and Student Achievement. (Working Paper \#3). Washington DC: Calder Urban Institute, National Center for Analysis of Longitudinal Data in Education Research.

Hasbrouck, J., \& Tindal, G. A. (2006). Oral Reading Fluency Norms: A Valuable Assessment Tool for Reading Teachers. The Reading Teacher, 59, 636-644. https://doi.org/10.1598/RT.59.7.3

Henderson, E. H., \& Templeton, S. (1986). A Developmental Perspective of Formal Spelling Instruction through Alphabet, Pattern, and Meaning. The Elementary School Journal, 86, 317-323. https://doi.org/10.1086/461451

Huang, L. (2014). Learning to Read with the Whole Language Approach: The Teacher's View. English Language Teaching, 7, 71-77. https://doi.org/10.5539/elt.v7n5p71

Introduction to SAS. UCLA: Statistical Consulting Group. https://stats.idre.ucla.edu/sas/modules/sas-learning-moduleintroduction-to-the-feature s-of-sas/

Jimenez, R. T. (1997). The Strategic Reading Abilities and Potential of Five Low-Literacy Latina/o Readers in Middle School. Reading Research Quarterly, 32, 224-243. https://doi.org/10.1598/RRQ.32.3.1

Kato, T., \& Manning, M. (2007). Content Knowledge-The Read Reading Crisis. Childhood Education, 83, 238-239. https://doi.org/10.1080/00094056.2007.10522922

Kennedy, M. M. (1998). Form and Substance in in-Service Teacher Education. Madison, WI: University of Wisconsin National Institute for Science Education. https://www.msu.edu/ mkennedy/publications/valuePD.html

Kennedy, M. M. (2016). How Does Professional Development Improve Teaching? Review of Educational Research, 86, 945-980. https://doi.org/10.3102/0034654315626800

Kentucky Department of Education (2017). Kentucky Department of Education School Report Card 2016-17. https://education.ky.gov/AA/distsupp/Pages/SRC.aspx

Kentucky General Assembly (1990). “Kentucky Education Reform Act of 1990.” Regular Session 1990, House Bill 940, Section 104. Frankfort, KY: Kentucky General Assembly.

Lewis, C. (2009). What is the Nature of Knowledge Development in Lesson Study? Educational Action Research, 17, 95-110. https://doi.org/10.1080/09650790802667477

Licklider, B. L. (1997). Breaking Ranks: Change the in-Service Institution. NASSP Bulletin, 81, 9-22. https://doi.org/10.1177/019263659708158504

Luft, J. A., \& Hewson, P. W. (2014). Research on Teacher Professional Development in Science. In N. G. Lederman, \& S. K. Abel (Eds.), Handbook of Research on Science Education (Vol. 2, pp. 889-910). New York: Routledge.

Manzo, K. K. (2000). Dallas Reading Initiative Produces Limited Results. Education Week, 19, 11. https://www.edweek.org/ew/articles/2000/03/01/25read.h19.html

Marsh, J. A., McCombs, J. S., Lockwood, J. R., Martorell, F., Gershwin, D., Naftel, S. et al. 
(2008). Supporting Literacy across the Sunshine State: A Study of Florida Middle School Reading Coaches. Santa Monica, CA: RAND.

McGlinchey, M. T., \& Hixson, M. D. (2004). Using Curriculum-Based Measurement to Predict Performance on State Assessments in Reading. School Psychology Review, 33, 193-203.

MetaMetrics (2016). The Lexile Framework for Reading. https://www.lexile.com/analyzer/

Moats, L. C. (2004). The Professional Development of Reading Teachers. In P. McCardle, \& V. Chhabra (Eds.), The Voice of Evidence in Reading Research. Baltimore, MD: Paul H. Brookes Publishing Co.

National Assessment of Educational Progress (NAEP) (2017). 2017 Reading Assessment. U.S. Department of Education, Institute of Education Sciences, National Center for Education Statistics, National Assessment of Educational Progress (NAEP). https://www.nationsreportcard.gov/media.aspx

National Council of Teachers of Mathematics (1991). Commission on Teaching Standards for School Mathematics: Professional Standards for Teaching Mathematics. Reston, VA: National Council of Teachers of Mathematics.

National Institute of Child Health and Human Development (2000). Report of the National Reading Panel: Teaching Children to Read: An Evidence-Based Assessment of the Scientific Research Literature on Reading and Its Implications for Reading Instruction. Washington DC: U.S. Government Printing Office.

Newman, S. B., \& Cunningham, L. (2009). The Impact of Professional Development and Coaching on Early Language and Literacy Practices. American Educational Research Journal, 46, 532-566. https://doi.org/10.3102/0002831208328088

Paige, D. D., Smith, G. S., Rasinski, T. V., Rupley, W. H., Magpuri-Lavell, T., \& Nichols. W. D. (2019). A Path Analytic Model Linking Foundational Skills to Grade 3 State Reading Achievement. Journal of Educational Research, 112, 110-120. https://doi.org/10.1080/00220671.2018.1445609

Penuel, W. R., Fishman, B. J., Gallagher, L, P., Korbak, C., \& Lopez-Prado, B. (2009). What Makes Professional Development Effective? Strategies that Foster Curriculum Implementation. American Educational Research Journal, 44, 921-958. https://doi.org/10.3102/0002831207308221

Peterson, P. L., \& Comeaux, M. A. (1990). Evaluating the Systems: Teachers' Perspectives on Teacher Evaluation. Educational Evaluation and Policy Analysis, 12, 3-24. https://doi.org/10.3102/01623737012001003

Rayner, K., Pollatsek, A., Ashby, J., \& Clifton Jr., C. (2012). Psychology of Reading. New York: Psychology Press.

Reinking, D., \& Bradley, B. A. (2004). Connecting Research and Practice Using Formative Design Experiments. In N. K. Duke, \& M. H. Mallette (Eds.), Literacy Research Methodologies (pp. 149-169). New York: Guilford Press.

Reutzel, D. R., Dole, J. A., Fawson, P. C., Jones, C. D., Read, S., Fargo, J. D. et al. (2009). Connecting Primary Grade Teacher Knowledge to Primary Student Achievement: Developing an Evidence-Based Assessment Tool-The Literacy Instruction Knowledge Scales (LIKS). Washington DC: U.S. Department of Education, Institute of Education Sciences.

Richardson, J. T. E. (1998). The Availability and Effectiveness of Reported Mediators in Associative Learning: A Historical Review and an Experimental Investigation. Psychonomic Bulletin \& Review, 5, 587 -614. https://doi.org/10.3758/BF03208837 
Roy, M., \& Chi, M. T. H. (2005). The Self-Explanation Principle in Multimedia Learning. In R. E. Mayer (Ed.), Cambridge Handbook of Multimedia Learning (pp. 271-286). New York: Cambridge University Press. https://doi.org/10.1017/CBO9780511816819.018

Sailors, M., \& Price, L. R. (2010). Professional Development that Supports the Teaching of Cognitive Reading Strategy Instruction. The Elementary School Journal, 110, 301-322. https://doi.org/10.1086/648980

Seidenberg, M. (2017). Language at the Speed of Sight: How We Read, Why so Many Can't, and What Can Be Done about It. New York: Basic Books

Shewhart, W. A. (1980). Economic Control of Quality of Manufactured Product. Milwaukee, WI: Quality Press.

Shulman, L. (1986). Paradigms and Research Programs in the Study of Teaching: A Contemporary Perspective. In M. C. Witrock (Ed.), Handbook of Research in Teaching (3rd ed., pp. 3-36). New York: Macmillan.

Shulman, L. (1987). Knowledge and teaching: Foundations of the new reform. Harvard Educational Review, 57, 1-23. https://doi.org/10.17763/haer.57.1.j463w79r56455411

Snow, C. E., Burns, M. S., \& Griffin, P. (1998). Preventing Reading Difficulties in Young Children. Washington DC: National Academy Press.

Snow, C., \& Griffin, P. (2007). Knowledge to Support the Teaching of Reading: Preparing Teachers for a Changing World. San Francisco, CA: Jossey-Bass.

Sparks, D., \& Loucks-Horsely, S. (1990). Models of Staff Development. In J. Sikula (Ed.), Handbook of Research on Teacher Education (pp. 234-250). New York: MacMillan Publishing Company.

Taylor, M., \& Otinsky, G. (2007). Becoming Whole Language Teachers and Social Justice Agents: Pre-Service Teachers Inquire with Sixth Graders. International Journal of Progressive Education, 3, 68-83. http://www.inased.org/v3n2/IJPEv3n2.pdf

Torgesen, J. K., Wagner, R. K., \& Rashotte, C. A. (2014). Test of Word Reading Efficiency (2nd ed.). Austin, TX: Pro-Ed.

Truesdale, W. T. (2003). The Implementation of Peer Coaching on the Transferability of Staff Development to Classroom Practice in Two Selected Chicago Public Elementary Schools. Chicago, IL: Loyola University of Chicago.

Van Kuijk, M. F., Deunk, M. I., Bosker, R. J., \& Ritzema, E. S. (2016). Goals, Data Use, and Instruction: The Effect of a Teacher Professional Development Program on Reading Achievement. School Effectiveness and School Improvement, 27, 135-156. https://doi.org/10.1080/09243453.2015.1026268

Vanderburg, M., \& Stephens, D. (2010). The Impact of Literacy Coaches: What Teachers Value and How Teacher Change. Elementary School Journal, 111, 141-163. https://doi.org/10.1086/653473

Wenglinsky, H. (2000). How Teaching Matters: Bringing the Classroom Back into Discussions of Teacher Quality. A Policy Information Center Report. Princeton, NJ: The Milken Family Foundation and Educational Testing Service.

http://files.eric.ed.gov/fulltext/ED447128.pdf

Wharton-McDonald, R., Pressley, M., \& Hampston, J. M. (1998). Literacy Instruction in Nine First-Grade Classrooms: Teacher Characteristics and Student Achievement. The Elementary School Journal, 99, 101-128. https://doi.org/10.1086/461918

Yang, L., \& Tsiatis, A. (2001). Efficiency Study of Estimators for a Treatment Effect in a Pretest-Posttest Trial. The American Statistician, 55, 314-321.

https://doi.org/10.1198/000313001753272466 
Yoon, K. S., Duncan, T., Lee, S. W., Scarloss, B., \& Shapley, K. L. (2007). Reviewing the Evidence on How Teacher Professional Development Affects Student Achievement (Issues \& Answer Report, RL, 2007-No. 033). Washington DC: U.S. Department of Education, Institute of Education Sciences, National Center for Education Evaluation and Regional Assistance, Regional Educational Laboratory Southwest.

https://files.eric.ed.gov/fulltext/ED498548.pdf 